\title{
H-reflex amplitude depression as a marker of presynaptic inhibition in Painful Diabetic Neuropathy (PDN).
}

\author{
Ahmad Asmedi*, Samekto Wibowo, Lucas Meliala \\ Department of Neurology, Faculty of Medicine Universitas Gadjah Mada / \\ Dr Sardjito Hospital, Yogyakarta, Indonesia
}

DOI: http://dx.doi.org/10.19106/JMedSci004701201504

\begin{abstract}
Painful Diabetic Neuropathy (PDN) is a common complication of diabetes mellitus (DM). Disruption in presynaptic inhibition in dorsal horn of the spinal cord has been proposed as one of the pathomechanism of PDN. Previous research showed that presynaptic inhibition can be detected by H-reflex examination. The aim of this study was to know whether the reduction of presynaptic inhibition in spinal dorsal horn of PDN patients really exist, and detectable by $\mathrm{H}$-reflex examination. It was cohort prospective involving 141 (58 men, 83 women) patients with DM and impaired glucose tolerance (IGT) between the ages of 40 and 61 years from several health facilities in Yogyakarta. All patients underwent clinical, laboratory and electrodiagnostic examination. Demographic, clinical and electrodiagnostic data were collected and analyzed. By survival analysis there were 25 new cases of PDN (12.12\% cumulative incidence). Using survival Kaplan Meier analysis, the significant hazard ratio for PDN were 12.81 for median motor nerve amplitude, 5.74 for median nerve distal latency, 3.71 for median sensory nerve amplitude, 6.33 for median sensory latency, 3.4 for tibial nerve amplitude, 3.48 for tibial nerve distal latency, 2.29 for sural nerve amplitude, 4.47 for sural nerve latency, 3.99 for $\mathrm{H}$-reflex latency, $5.88 \mathrm{for} \mathrm{H}$-reflex amplitude, and 17.83 for Diabetic Neuropathy (DN) status. Using hazard proportional cox analysis, only $\mathrm{H}$ amplitude and DN status (DNS score) were significantly correlated with PDN $(p=0.026$; hazard ratio $=15.450 ; \mathrm{Cl} 95 \%=1.39-171.62$ for $\mathrm{H}$ amplitude and $p=0.030$; hazard ratio $=10.766 ; \mathrm{Cl} 95 \%=1.26-92.09$ for DN status).

This study showed that depression of H-reflex amplitude was correlated with the occurrence of PDN. This result proves that there was presynaptic inhibition process in PDN that manifests as low H-reflex amplitude.
\end{abstract}

\section{ABSTRAK}

Nyeri neuropati diabetik (PDN) merupakan suatu komplikasi yang umum pada diabetes mellitus (DM). Gangguan pada penghambatan presinaptik pada bagian dorsal horn dari sumsum tulang belakang diduga menjadi salah satu patomekanisme dari PDN. Penelitian sebelumnya menunjukkan bahwa penghambatan presinaptik dapat dideteksi dengan pemeriksaan H-refleks. Tujuan dari penelitian ini adalah untuk mengetahui apakah pengurangan inhibisi presinaptik di dorsal horn tulang belakang pasien PDN benar-benar ada, dan terdeteksi oleh pemeriksaan H-refleks. Penelitian ini adalah kohort prospektif yang melibatkan 141 (58 laki-laki, 83 perempuan) pasien DM dengan gangguan tolerasi glukosa berumur antara 40 sampai 61 tahun di

\footnotetext{
$\overline{\text { * corresponding author: aasmedi@yahoo.com }}$
} 
Ahmad Asmedi et al., H-reflex amplitude depression as a marker of presynaptic inhibition in Painful Diabetic Neuropathy (PDN)

berbagai rumah sakit di Yogyakarta.

Semua pasien menjalani pemeriksaan klinis, laboratorium dan pemeriksaan elektrodiagnostik. Data demografi, klinis dan electrodiagnostic dikumpulkan dan dianalisis. Berdasarkan analisis survival ada 25 kasus baru PDN (kejadian kumulatif 12,12\%). Dengan menggunakan analisis survival Kaplan Meier, Rasio hazard yang signifikan untuk PDN adalah 12,81 untuk median amplitudo saraf motorik, 5.74 untuk median latensi distal saraf, 3,71 untuk median amplitudo saraf sensorik, 6.33 untuk median latensi sensorik, 3,4 untuk amplitudo tibialis saraf, 3,48 untuk latensi saraf tibialis distal, 2,29 untuk amplitudo saraf sural, 4,47 untuk latensi saraf sural, 3,99 untuk latensi H-refleks, 5,88 untuk amplitudo H-refleks, dan 17,83 status Diabetes Neuropati (DN). Dengan menggunakan analisis cox proporsional hazard, hanya amplitudo $\mathrm{H}$ dan status DN (skor DNS) yang secara signifikan berkorelasi dengan PDN ( $p=0,026$; rasio hazard = 15,450; $\mathrm{Cl} 95 \%=1,39-171,62$ untuk amplitudo $\mathrm{H}$ dan $\mathrm{p}=0,030$; rasio hazard $=10,766 ; \mathrm{Cl} 95 \%=1,26-92,09$ untuk status DN). Penelitian ini menunjukkan bahwa depresi amplitudo $\mathrm{H}$-refleks berkorelasi dengan terjadinya PDN. Hasil ini membuktikan bahwa ada proses penghambatan presinaptik di PDN yang bermanifestasi pada rendahnya amplitudo H-refleks.

Keywords: Painful diabetic neuropathy - H-reflex amplitude - presynaptic inhibition Diabetes Mellitus

\section{INTRODUCTION}

Painful Diabetic Neuropathy (PDN) is a common complication of diabetes mellitus (DM), which can give large burdens because of its high incidence, serious clinical, economical and social impact and its unsatisfying treatment. ${ }^{1,2}$

Biological process in spinal dorsal horn has been shown to have an important role in pathophysiology of PDN. Gate mechanism in the dorsal horn of the spinal cord plays a role by inhibiting or facilitating the flow of afferent impulses from peripheral nerves to the spinal cord before it evokes pain perception. ${ }^{3}$ Many research have shown that diminished synaptic inhibition plays a key role in neuropathic pain development. ${ }^{4}$ Normally, GABA ${ }_{\mathrm{A}}$ receptors in primary afferent terminals of nociceptors will mediate this presynaptic inhibition by causing reduction of transmitter release thus modulating the afferent input from dorsal root ganglion neurons into nociceptive projection neurons (presynaptic inhibition). ${ }^{4}$ In PDN this process was disturbed, leading to neuropathic pain. ${ }^{5}$
H-reflex is an electrically induced reflex analogous to the mechanically induced spinal stretch reflex. ${ }^{6}$ The H-reflex bypasses the muscle spindle. Therefore, it is a valuable tool in assessing modulation of monosynaptic reflex activity in the spinal cord. ${ }^{6}$ The H-reflex is an estimate of alpha motoneuron (aMN) excitability when presynaptic inhibition and intrinsic excitability of the aMNs remain constant. This measurement can be used to assess the responsiveness of the nervous system to various neurologic conditions including pain ${ }^{7}$, hence H-reflex amplitude can be proposed as a method to assess presynaptic inhibition in humans.

The aim of this study was to know whether the reduction of presynaptic inhibition in spinal dorsal horn of PDN patients really exist, and detectable by H-reflex examination.

\section{SUBJECTS \& METHODS}

The design of this study was cohort prospective. The inception cohort was diabetes mellitus patients free from PDN (ID 
Pain score below 2), followed by a 12-months disease follow-up. The protocol was approved by the Research Ethics Committees of Faculty of Medicine, Universitas Gadjah Mada, and all subjects were provided with written informed consent. The subjects of this study were patients at diabetes outpatient clinic Dr Sardjito Hospital Yogyakarta, members of diabetes association (Persatuan Diabetes Indonesia, PERSADIA) PKU Hospital Yogyakarta, staffs of STIKES Aisiyah Yogyakarta and the subjects from Pre-diabetic Research of Clinical Pathology Department at Dr Sardjito Hospital Yogyakarta.

The inclusion criteria were men and women 20 to 60 year-old, with type 2 diabetes mellitus or impaired glucose tolerance (IGT), as defined by American Diabetes Association (ADA) criteria. The exclusion criteria were anatomical deformities on extremities that would interfere with electrodiagnostic study protocol; pregnancy or lactation; a documented history of lumbosacral surgery that would interfere with electrodiagnostic study protocol; other diseases known to be associated with pain, especially chronic pain in the feet that the investigator believed would interfere with the assessment of pain associated with diabetic neuropathy, like cancer pain, lumbosacral abnormality or other entrapment neuropathy; and any acute or underlying serious illness that are likely interfere with completion of the trial .

Clinical and electrodiagnostic examinations were peformed in all patients. Baseline assessments, consisted of ID pain, neuropathy symptom score (NSS), diabetic neuropathy symptom (DNS), review of nerve conduction study of upper and lower extremity, and soleus H-reflex study were done at week 1. Nerve conduction study and H-reflex were conducted using an MEB-2300K ENMG machine (Nihon Kohden, Tokyo, Japan). The evaluation and record of PDN occurrence were carried out every week up to 12 months by self-assessment, monitored by the doctors.

The Kaplan Meier survival analysis was conducted to see the ability of several electrodiagnostic variables to predict the possibility of subjects to suffer from PDN during the observation period. For this reason, the ID pain was measured periodically every 2 weeks, to assess the PDN status of the subjects. The data analyses were presented in TABLE of Kaplan Meier analysis, hazard ratio, and survival curve.

\section{RESULTS}

One hundred and forty one subjects ( 58 men, 83 women) with an average age of 51 years old (range, 40-61 years old), were enrolled in this study. Sixty five percent of the subjects were found to be diabetic, while the other $35 \%$ were found to have IGT. The mean glucose level was $116 \mathrm{mg} / \mathrm{dl}$ (range, 78 - 200 $\mathrm{mg} / \mathrm{dL}$ ) for fasting, $170 \mathrm{mg} / \mathrm{dL}$ for 2 hours post prandial (range, $90-250 \mathrm{mg} / \mathrm{dL}$ ).

Screening by NSS and DNS scores at admission found that 57 subjects (40.4\%) were diagnosed as neuropathy (Diabetic Neuropathy/DN) according to NSS, while $68(48.2 \%)$ were diagnosed as neuropathies according to DNS. There were no subjects diagnosed as PDN. However, upon completion of 48 weeks of observation, there were $12.12 \%$ cumulative incidence rate of PDN. 
Ahmad Asmedi et al., H-reflex amplitude depression as a marker of presynaptic inhibition in Painful Diabetic Neuropathy (PDN)

TABLE 1. Hazard ratio of PDN factor

\begin{tabular}{llrrl}
\hline & & \multicolumn{1}{l}{ HR } & \multicolumn{1}{c}{$p$} & \multicolumn{1}{l}{ CI 95\% } \\
\hline \multirow{4}{*}{ Median } & Amplitude & 12.81 & 0.01 & $1.69-96.10$ \\
\cline { 2 - 5 } & Distal latency & 5.74 & 0.01 & $1.63-20.13$ \\
\cline { 2 - 5 } & $\begin{array}{l}\text { Nerve Conduction } \\
\text { Velocity }\end{array}$ & 2.39 & 0.09 & $0.89-6.41$ \\
\cline { 2 - 5 } & Sensory amplitude & 3.71 & 0.04 & $1.06-13.01$ \\
\cline { 2 - 5 } Tibial & Sensory latency & 6.33 & $<0.001$ & $2.20-18.24$ \\
\hline \multirow{3}{*}{ Sural } & Amplitude & 3.40 & 0.02 & $1.18-9.78$ \\
\cline { 2 - 5 } & Distal latency & 3.48 & 0.01 & $1.30-9.35$ \\
\cline { 2 - 5 } H-reflex & NCV & 1.13 & 0.81 & $0.42-3.041$ \\
\hline Hyperglycemic status & Amplitude & 2.29 & 0.10 & $0.85-6.16$ \\
\cline { 2 - 5 } & Latency & 3.74 & $<0.001$ & $1.72-13.04$ \\
\hline DN & Latency & 3.99 & 0.03 & $1.14-14.00$ \\
\cline { 2 - 5 } & H Amplitude & 45.34 & 0.01 & $1.67-20.63$ \\
\hline
\end{tabular}

The low amplitude of median and tibial nerve had significant value in predicting PDN occurence with hazard ratio 12.81 for median nerve amplitude $(95 \%$ CI $1.69-96.10, p=$ $0.01)$ and 3.4 for tibial nerve amplitude $(95 \%$ CI $1.18-9.78, p=0.02$ ), while sural nerve with hazard ratio 2.29 was not significant $(95 \%$ CI $0.85-6.16, p=0.10)$. Distal latency of median, tibial, and sural nerve were also related significantly with PDN occurrence with hazard ratio 5.74 for median nerve $(95 \%$ CI $1.63-20.13, p=0.01), 3.48$ for tibial nerve (95\% CI $1.18-9.78, p=0.02)$, and 4.74 for sural nerve latency $(95 \%$ CI $1.72-13.04$, $p<0.001)$. Median nerve sensory amplitude and sensory latency were also significant with hazard ratio $3.71(95 \%$ CI $1.06-13.01, p=$ $0.04)$ and 6.33 (95\% CI $2.20-18.24, p<0.001)$, respectively. Beside sural nerve amplitude, the nerve conduction velocity of median nerve (hazard ratio $=2.39$ ) and tibial nerve (hazard ratio $=1.13$ ) were not significant.

The hazard ratio for H-reflex latency was 3.99 (95\% CI 1.14 - 14.00) and for H-reflex amplitude was 5.88 (95\% CI 1.67 - 20.63). These variables were also significantly related to PDN occurrence with $p$ value 0.03 and 0.01 respectively. Beside the electrodiagnostic variables, the clinical variables were also measured. The status of DN with hazard ratio $17.83(95 \%$ CI $1.63-20.14, p=0.01)$ was significantly related to the occurence of PDN, while the hyperglycemic status had high hazard ratio (45.43) but was not significant (95\% CI $0.71-2897.64, p=0.07)$.

This analysis showed that neuropathy status (clinical and electrodiagnostic), was closely related to PDN occurrence. 
TABLE 2. Analysis of PDN Survival Cox regression

\begin{tabular}{lllll}
\hline \multicolumn{1}{c}{ Variable } & \multicolumn{1}{c}{ Parameter } & \multicolumn{1}{c}{ P } & \multicolumn{1}{c}{ CI 95\% } \\
\hline H-reflex & H Amplitude & 0.026 & 15.450 & $1.39-171.62$ \\
\hline DN Status & DNS score & 0.030 & 10.766 & $1.26-92.09$ \\
\hline H-reflex & Latency & 0.764 & 0.783 & $0.16-3.88$ \\
\hline \multirow{3}{*}{ Median } & Distal latency & 0.458 & 1.736 & $0.40-7.45$ \\
\cline { 2 - 5 } & NCV & 0.763 & 0.836 & $0.26-2.68$ \\
\cline { 2 - 5 } & Sensory & 0.699 & 0.757 & $0.18-3.10$ \\
& Amplitude & & & \\
\cline { 2 - 5 } Tibial & Sensory latency & 0.136 & 2.942 & $0.71-12.16$ \\
\hline \multirow{2}{*}{ Sural } & Amplitude & 0.179 & 0.311 & $0.06-1.71$ \\
\cline { 2 - 5 } & Distal latency & 0.159 & 2.528 & $0.70-9.18$ \\
\hline & Sensory & 0.293 & 0.499 & $0.14-1.82$ \\
\cline { 2 - 5 } & Amplitude & & & \\
\hline
\end{tabular}

All variables that were significant in Kaplan Meier analysis were compared using Cox regression analysis. This analysis showed that only H-reflex amplitude and DN status (measured by DNS score) were significantly related to PDN occurrence. The hazard ratio for H-reflex amplitude was 15.450 (95\% CI $1.39-171.62, p=0.026)$, and for DN status was 10.766 (95\% CI $1.26-92.09, p=0.030)$. Despite of the widened confidence interval, H-reflex amplitude had the highest hazard ratio among the other predictor variables. This result proved that there was presynaptic inhibition process in PDN that manifested as low H-reflex amplitude.

\section{DISCUSSION}

The study population in this research was patients with abnormality in blood glucose level (DM or IGT). After observation for almost 12 months, $40 \%$ of patients had neuropathy and 12\% had PDN. Demographic data showed that hyperglycemic and neuropathic status significantly predict PDN. This result inherent to mechanisms proposed by Fink and Oaklander ${ }^{8}$ that disruption of nerve function as a result of glucose accumulation in the nerve include abnormal metabolic product formation and focal tissue ischemia in sensory and autonomic nerves as a result of endoneural hypoxia. The excess of glucose and oxidative stress, aberrant neurofilament phosphorylation, disruption of normal nerve growth factors and mitochondrial dysfunction in the dorsal root ganglia, disturb normal function of tissue repair mechanisms. ${ }^{8}$

This study found that several variables of NCS were significantly related to PDN. Longterm changes are likely occur after injury, both peripherally and centrally. ${ }^{9}$ Because NCS basically evaluates peripheral nerves, these positive results indicate the likelihood that peripheral nerve abnormality has contribution in PDN development. According to Zhuo, ${ }^{9}$ the injury and injury-related areas undergo longterm plastic changes resulting in significantly enhanced pain sensation (hyperalgesia) or misinterpretation of non-noxious stimuli as pain (allodynia). Unlike physiological pain, pathological pain happens only after injury (e.g., tissue or nerve injury), and is not a result 
Ahmad Asmedi et al., H-reflex amplitude depression as a marker of presynaptic inhibition in Painful Diabetic Neuropathy (PDN)

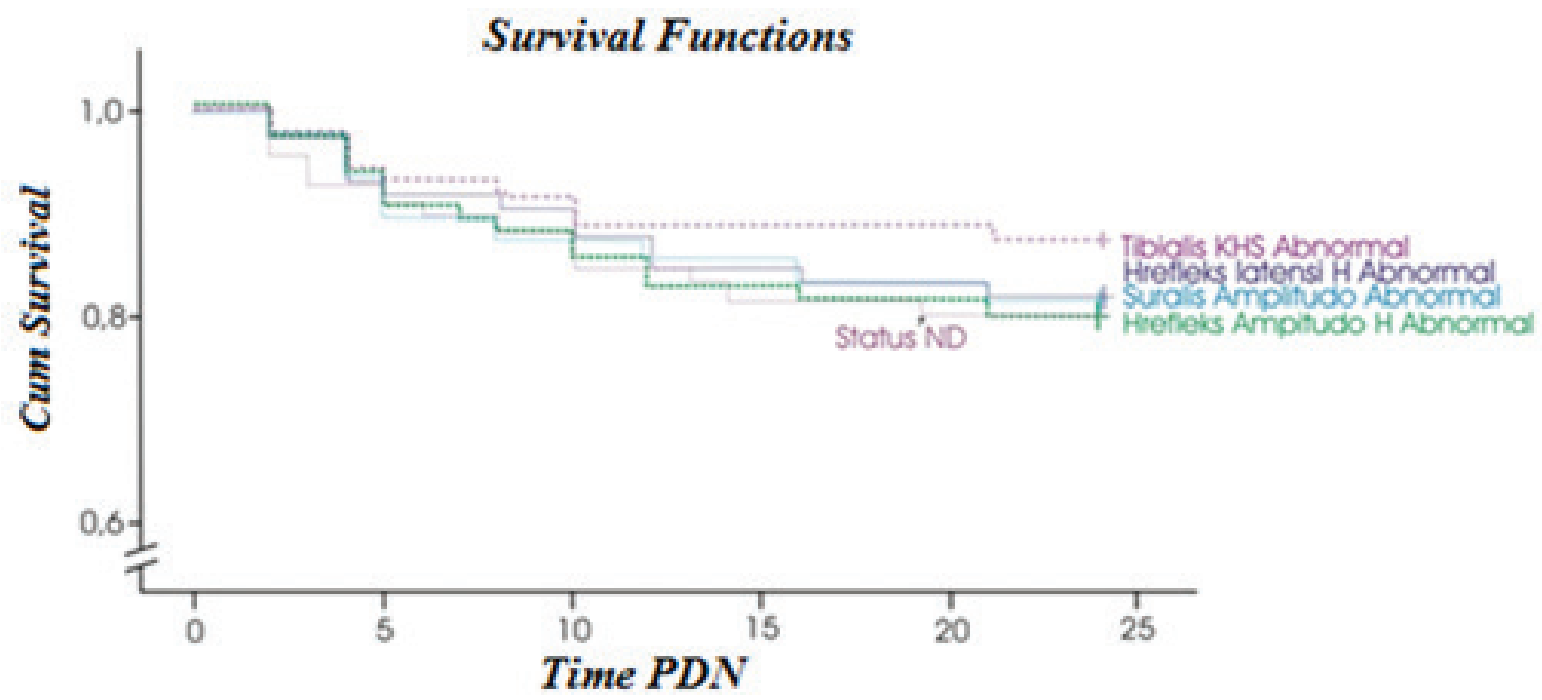

FIGURE 1. Survival diagram of PDN occurence from several predictor variables (the abnormality of tibial nerve conduction velocity, H-reflex latency, sural amplitude, and H-reflex amplitude).

of repetitive application of physiological pain. ${ }^{9}$

One of the reasons why so many changes happen following a nerve injury is that sensory neurons, and the non-neural cells associated with them, are highly interdependent in generating pain. ${ }^{10}$ The molecular mechanisms of pain generation in PDN are multifactorial and not fully understood. The predominantly involved is distal axon. This is related to the dependence of distal axon upon oxidative metabolism to sustain axonal transport. Disruption in the supply of blood, oxygen, glucose, ATP, or NADPH will disturb the transport, which will lead to distal axonal degeneration. ${ }^{8}$

Analysis using Kaplan Meier survival in this study showed that $\mathrm{H}$ latency and amplitude are related to hazard ratio and the $p$ value. H-reflex represents activity of peripheral and central nervous system. Therefore, our result indicated that there was probably abnormal function in the central region (dorsal horn of the spinal cord) which contributes to the generation of PDN. Gate control theory proposed that normal processing of nociceptive and non-nociceptive stimuli relies on a complex processing which consists of presynaptic and postsynaptic inhibitory control mechanism in the spinal dorsal horn. Under healthy condition, this inhibition is responsible in keeping the nociceptive and non-nociceptive modalities apart. The loss of this inhibition process has been widely accepted to lead to chronic pain. Blockade of this inhibition mechanism has been shown to cause hyperalgesia and tactile allodynia, two major symptoms of chronic pain. This has been supported by many research showed decrease in inhibition, or "disinhibition", as an important substrate of many chronic pain models. ${ }^{4}$ This disinhibition will result in increasing neurons excitability and enable excitatory input from non-nociceptive fiber to nociceptive projection neurons. ${ }^{4}$

This is a part of a process called central sensitization, which arises after a chronic pain. Central sensitization is an enhancement in the functional status of neurons and circuits in nociceptive pathways caused by 
increases in membrane excitability, synaptic efficacy, or a reduced inhibition in dorsal horn neurons in response to nociceptor input. ${ }^{11}$ Sensitization of dorsal horn neurons occurs after various types of tissue damage including thermal injury, chemical injury, polyarthritis or after stimulation of C-fiber afferents. ${ }^{12}$ After peripheral nerve injury, damaged and nondamaged $\mathrm{A}$ - and $\mathrm{C}$-fibers begin to generate spontaneous action potentials which will drive central sensitization. ${ }^{11}$ Repeated C-fiber afferent stimulation also produces a sequential increase in dorsal horn activity resulting in a prolonged discharge of the cell (wind-up). ${ }^{12}$ The stimuli that induce wind-up can lead to central sensitization. ${ }^{11}$

Structural changes in peripheral nerve injury also contribute to altered synaptic function. Peripheral nerve injury leads to a transganglionic degeneration of $\mathrm{C}$-fiber terminals in lamina II. ${ }^{11}$ This will deprive pain transmission neurons in the superficial dorsal horn of their normal nociceptive input, and causes patients to experience negative symptoms. ${ }^{13}$ There will be increases in the intrinsic axonal growth capacity as part of the regenerative response of the injured neurons, which will result in sprouting of myelinated A- $\beta$ fibers from lamina III-IV into lamina I-II and make contact with nociceptive-specific neurons. ${ }^{11}$ As a result, stimulation of low threshold mechanoreceptors abnormally activates pain transmission neurons in lamina II of the spinal cord. ${ }^{13}$

Diminished synaptic inhibition has also been acknowledged to have a key role in neuropathic pain development. ${ }^{5}$ Normally, $\mathrm{GABA}_{\mathrm{A}}$ receptors in primary afferent terminals of nociceptors will mediate this presynaptic inhibition by causing reduction of transmitter release thus modulating the afferent input from dorsal root ganglion neurons into nociceptive projection neurons (presynaptic inhibition). ${ }^{4}$ In PDN this presynaptic inhibition was disturbed, which ultimately caused neuropathic pain. This disinhibition in the superficial dorsal horn is caused by the loss of GABAergic and a reduction in glycinergic inhibitory currents. Apoptosis of inhibitory interneurons, caused by NMDAR-induced cytotoxicity, has been proposed as the cause of this disinhibition. ${ }^{11}$

Presynaptic inhibition constitutes an inhibitory mechanism associated with modulation of monosynaptic reflexes. Therefore, examination of monosynaptic reflex should be able to detect this pre-synaptic inhibition. One of the proposed methods is by assessing H-reflex. Our result showed that this presynaptic inhibition can indeed be assessed by H-reflex. The H-reflex is evoked by lowintensity electrical stimulation of the afferent nerve resulting in monosynaptic excitation of $\alpha$-motoneurons. Changes in the amount of presynaptic inhibition acting on Ia afferent terminals has been associated with soleus H-reflex modulation. Soleus H-reflex has been shown to be more sensitive to presynaptic inhibition than the mechanically evoked ankle stretch reflex. ${ }^{6}$

\section{CONCLUSIONS}

This result proved that there was presynaptic inhibition process in PDN that manifested as low H-reflex amplitude. Our result also showed that depression of $\mathrm{H}$-reflex amplitude is correlated with the occurrence of PDN. This indicated that H-reflex amplitude depression can be used as a marker for presynaptic inhibition in PDN for management of patients with PDN in the future.

\section{ACKNOWLEDGMENTS}

The researchers would like to thank all patients who have participated in this study. 


\section{REFERENCES}

1. Kirby M. Painful diabetic neuropathy-current understanding and management for the primary care team. Br J Diabetes Vasc Dis 2003; 3:138-44. http://dx.doi.org/10.1177/1474651403003002100 1

2. Baron R. Mechanisms of Disease: neuropathic pain--a clinical perspective. Nat Clin Pract Neurol 2006; 2(2):95-106. http://dx.doi.org/10.1038/ncpneuro0113

3. Aslam A, Singh J, Rajbhandari S. Pathogenesis of painful diabetic neuropathy. Pain Res Treat 2014; 2014.

4. Guo D, Hu J. Spinal presynaptic inhibition in pain control. Neuroscience 2014; 283:95-106. http://dx.doi.org/10.1016/j. neuroscience.2014.09.032

5. Scholz J, Broom DC, Youn D-H, Mills CD, Kohno T, Suter MR et al. Blocking caspase activity prevents transsynaptic neuronal apoptosis and the loss of inhibition in lamina ii of the dorsal horn after peripheral nerve injury. J Neurosci 2005; 25(32):7317-23.

http://dx.doi.org/10.1523/

JNEUROSCI.1526-05.2005

6. Knikou M. The H-reflex as a probe: pathways and pitfalls. J Neurosci Methods 2008; 171(1):1-12. http://dx.doi.org/10.1016/j.jneumeth.2008.02.012
7. Palmieri RM, Ingersoll CD, Hoffman MA. The hoffmann reflex: methodologic considerations and applications for use in sports medicine and athletic training research. J Athl Train 2004; 39(3):268-77.

8. Fink E, Oaklander A. Diabetic neuropathy. Pain Manag Rounds 2005; 2:309-14.

9. Zhuo M. Neuronal mechanism for neuropathic pain. Mol Pain 2007; 3:14. http://dx.doi.org/10.1186/1744-8069-3-14

10. Devor M. Neuropathic pain: what do we do with all these theories? Acta Anaesthesiol Scand 2001; 45(9):1121-7. http://dx.doi.org/10.1034/j.13996576.2001.450912.x

11. Latremoliere A, Woolf CJ. Central sensitization: a generator of pain hypersensitivity by central neural plasticity. J Pain 2009; 10(9):895-926. http://dx.doi.org/10.1016/j.jpain.2009.06.012

12. Coderre TJ, Katz J. Peripheral and central hyperexcitability: differential signs and symptoms in persistent pain. Behav Brain Sci 1997; 20(3):404-19. http://dx.doi.org/10.1017/S0140525X97251484

13. Taylor BK. Pathophysiologic mechanisms of neuropathic pain. Curr Pain Headache Rep 2001; 5(2):151-61. http://dx.doi.org/10.1007/s11916-001-0083-1 